Розділ III. Історичні та порівняльні аспекти в теорії і практиці духовно-інтелектуального виховання й навчання

\title{
ОСОБЛИВОСТІ ОРГАНІЗАЦІЇ ПРОСВІТИ БАТЬКІВ У ПРОВІДНИХ КРАЇНАХ СВІТУ
}

\section{Тарарак О. В.}

доктор філологічних наук, доцент, доцент кафедри німецької філології, Харківський національний педагогічний університет імені Г. С. Сковороди, м. Харків, Україна

\section{Тарарак М. Ю.}

кандидат філологічних наук, доцент, доцент кафедри німецької філології, Харківський національний педагогічний університет імені Г. С. Сковороди, м. Харків, Україна

У статті проаналізовано особливості організації просвіти батьків у краӥнах Західної Свропи та США. Визначено зміст даної діяльності, виділено організації, які займалися реалізацією зазначених питань у провідних краӥнах світу. 3'ясовано провідні шляхи ефективної реалізації питань, які вивчаються, а саме: розробка методичної літератури; створення відповідних програм та ін.

Ключові слова: просвіта батьків, молодь, особливості, організація.

The specific features of organization of parent education in Western European countries and the USA are analyzed in the article. The content of this activity is determined. The organizations which dealt with the implementation of these ideas are identified. The leading ways of effective implementation of the studied ideas are found out. They are: the development of methodical literature, drawing up appropriate training programs etc.

Key words: parent education, youth, specific features, organization.

Сьогодні українська держава проявляє активний інтерес до спілкування з провідними країнами світу та збагачення національної педагогічної теорії та практики кращими надбаннями світової думки. Важливе місце в цій співпраці займають питання організації просвіти батьків.

Вивчення та узагальнення світового педагогічно цінного досвіду дозволило визначити шляхи ефективної реалізації питань, які вивчаються, в провідних країнах світу. Це:

- наявність якісної методичної літератури для батьків;

- створення програм із батьківської просвіти, проведення конференцій та читання лекцій, створення батьківських асоціацій тощо. 
- активне залучення батьків до освітнього процесу;

- дієва практика підготовки молодого покоління до сімейного життя та батьківства.

Сьогодні, як свідчить проведене дослідження, робота з батьками включає такі напрями, як: захист прав та свобод дитини; роботу з проблемними дітьми; корекцію дитячої поведінки тощо. Діяльність школи з батьками, в свою чергу, поділяється на: вирішення соціальних проблем (робота з малозабезпеченими сім'ями, багатодітними родинами); організацію сімейно-виховної діяльності (сімейні консультації); соціальнопедагогічні втручання (здійснення підготовки батьків до справи виховання дітей, надання їм різнобічної допомоги й підтримки). Серед соціально-педагогічних втручань науковці розрізняють необхідність навчання батьків із метою поглиблення їхньої свідомості та використання їхніх виховних здібностей і соціовиховне втручання, котре передбачає дії, які здійснюються фахівцями, та спрямовані на допомогу, підтримку та пораду батькам щодо виконання ними завдань виховання дітей $[2 ; 3 ; 4]$.

Як свідчить проведене дослідження, перші письмові рекомендації для батьків у країнах Західної Європи та США з'являються в другій половині XVIII - на початку XIX століття, а перші посібники в 60-ті pp. XIX століття. Автори підручників для батьків у своїх працях пропонують численні поради та рекомендації стосовно здійснення належного виховання дітей та проводять лекції для матерів. До найбільш відомих посібників із навчання батьків, який і сьогодні широко використовують як вітчизняні, так і зарубіжні сім'ї, належить праця Бенджаміна Спока «Дитина та догляд за нею» (1946 рік). У вказаній праці, з метою надання батькам загального уявлення про світ дитини, американський дослідник, дитячий лікар і педагог створює «зібрання законів дитячого щастя та здоров'я».

Проведений ретроспективний аналіз дозволяє констатувати що, окрім великої кількості літератури для батьків, у XIX столітті в світі починають активно створюватися асоціації, котрі займалися проблемами дитини і вивчення впливу сімейного оточення на ії розвиток. Так, у 1815 році в Німеччині з метою широкого обговорення методів виховного впливу в Мюнхені збирається неформальна група батьків, яка в 1820 році об'єднується в «Материнську асоціацію». У 1888 році у США з метою вивчення дітей з різних боків (розумового, морального і фізичного) створюється Асоціація Вивчення Дітей Америки. 
Як свідчать науково-педагогічні матеріали зазначена Асоціація вивчала особливості розвитку дітей та їхнього виховання, значення сім'ї для малюків. Організація у своїх програмах широко використовувала сучасні досягнення в галузі соціології, психіатрії та психології і була однією $з$ перших, хто ознайомив батьків з ними. Одним із напрямів діяльності асоціації було читання циклу лекцій для батьків [2; 4].

Варто звернути увагу на те, що в провідних країнах світу (Німеччина, Франція, США та ін.) виховання відбувається без насилля. Наприклад, у п. 1631 Громадянського кодексу Німеччини прописано заборону використання до дітей фізичних покарань. Ці питання контролює Відомство у справах молоді.

Також зазначені Відомства займаються вирішенням і таких питань, як-от:

- забезпечення процесу всебічного розвитку дитини;

- соціальна допомога молоді;

- захист прав дітей;

- підтримка і допомога молодим сім'ям;

- допомога батькам у скрутних життєвих ситуаціях;

- організація виховних закладів денного типу;

- допомога батькам у вихованні дітей [3].

У Франції з метою допомоги батькам у вихованні дітей була створена спеціальна Асоціація Національної Взаємодопомоги Батькам (1976 рік).

Реалізацією питань батьківської просвіти в США займається Національний Конгрес Матерів (створений у 1895 році), який пізніше (1897 рік) було перейменовано в Асоціацію Батьків та Вчителів.

Починаючи з цього періоду залучення батьків до освітнього процесу стало розглядатися як один із варіантів створення партнерства між школою та сім'єю.

Головною тенденцією провідних країн світу стала активізація взаємодії школи з батьками та родиною. У світовій педагогічній думці все частіше стали з'являтися такі поняття, як: «батьківсько-шкільне виховання», «сімейно-вчительське партнерство» та ін.

Варто наголосити на тому, що сьогодні питаннями батьківської просвіти займаються провідні країни світу. Педагогічні працівники організують спеціальні курси для батьків із питань родинного виховання. На рівнях школи, мікрорайону, міста тощо діють батьківські 
асоціації, які займаються благодійною діяльністю, приділяють увагу неблагополучним сім'ям, проводять у школах гуртки або уроки як волонтери. Також в країнах Західної Свропи та США працюють батьківсько-вчительські асоціації. Їхня діяльність передбачає читання лекцій для батьків, проведення групових та індивідуальних бесід, зустрічей із батьками, відвідування дітей вдома тощо. В більшості провідних країн світу існує велика кількість програм, які навчають батьків у трьох вимірах:

- батьки - діти;

- батьки - діти - вчителі;

- підготовка працівників для роботи в сфері батьківської просвіти.

Особливістю функціонування сучасної системи батьківської просвіти країн Західної Свропи та США виступає диференціація програм для батьків (батьків-чоловіків; батьків, що мають дітей із різними відхиленнями в розвитку тощо).

Наприклад, у США велика увага приділяється питанням підготовки молоді до сімейного життя. Зокрема, у професійних коледжах почали навчати жінок домашньому господарству. Сьогодні в американських школах наука про ведення домашнього господарства виділяється як окремий предмет.

Взагалі, навчання сімейно-споживчим наукам проводилось у провідних країнах світу ще в середині XIX століття.

Наприкінці XIX століття у США було розроблено такі курси з ведення домашнього господарства для молодих жінок, як «Домашня економіка» та «Домашня наука», які знайомили слухачок із питаннями успішного ведення домашнього господарства, створення сприятливої атмосфери в будинку, вмілого розпорядження грішми, правами дитини, збереження здоров'я дітей, особливостями релігійного виховання та ін. [1].

Сьогодні, як стверджують наукові джерела, підготовка молоді до сімейного життя відбувається в таких напрямах, як: підготовка до шлюбу; організація статевого виховання; підготовка до відповідального батьківства [2].

Мета дошлюбної підготовки полягає у засвоєнні молоддю теоретичних знань про шлюб і інтимні взаємини. Організація статевого виховання молоді передбачає засвоєння знань із питань анатомії та 
фізіології організму людини і його репродуктивної системи; виховання в статевих взаєминах почуття відповідальності; усвідомлене сприйняття обов’язків і відповідальності сімейного життя [2].

Таким чином, до особливостей організації просвіти батьків у провідних країнах світу можна віднести: підготовку методичної літератури для батьків; розробку програм з питань батьківської просвіти, читання лекцій, заснування батьківських асоціацій; активне залучення батьків до участі в освітньому процесі школи; надання активної допомоги батькам у вихованні дітей; диференціація програм для батьків; вивчення науки про ведення домашнього господарства як окремого шкільного предмету.

\section{Список використаних джерел:}

1. Вендеровская Р. Б. Американская школа глазами американцев. Педагогика. 2000. №6. С. 85-90.

2. Глушич В. В. Проблеми виховання підлітків у сім'ях США : автореф. дис. ... канд. пед. наук. Харків, 2016, 20 с.

3. Фінчук Г. В. Теорія та практика сімейного виховання в зарубіжній педагогіці: автореф. дис. ... канд. пед. наук. Луганськ, 2001, 20 с.

4. Яворська Л. Г. Підготовка молоді до сімейного життя в США : автореф. дис. ... канд. пед. наук. Тернопіль, 2007, 20 с. 